\title{
The RNA structure of the major splice donor site controls HIV-1 splicing
}

\author{
Nancy Mueller*, Ben Berkhout, Atze Das \\ From Frontiers of Retrovirology: Complex retroviruses, retroelements and their hosts \\ Cambridge, UK. 16-18 September 2013
}

\section{Background}

The unspliced HIV-1 RNA is used as mRNA for translation of the Gag and Pol proteins and packaged as genomic RNA in the virion. In addition, HIV-1 produces more than 40 differentially spliced transcripts that encode the other viral proteins. Regulation of splicing is essential for the production of all unspliced and spliced viral RNAs. The 5 ' leader region of the HIV-1 RNA contains the major 5 ' splice site (5'ss) that is used in the production of all spliced RNAs. This splice donor (SD) region can fold a stem-loop structure and the stability of this hairpin may influence splicing by restricting the accessibility of the 5 'ss for the splicing machinery. To test this hypothesis, the thermodynamic stability of the SD hairpin was varied through mutation and the effect on RNA splicing was analyzed.

\section{Materials and methods}

The SD hairpin in the HIV-1 leader RNA region was stabilized or destabilized through mutation in the context of the HIV-1 molecular clone LAI. The effect on virus replication was measured upon infection of the SupT1 T cell line. The mutations were also introduced into an LTRluciferase plasmid. Upon transfection of these reporter constructs into $293 \mathrm{~T}$ cells, the efficiency of splicing at the major 5'ss was analyzed by luciferase activity assays and RNA analysis.

\section{Results}

Both stabilization and destabilization of the SD hairpin reduced HIV-1 replication. The LTR-luciferase experiments demonstrated that stabilization of the SD hairpin reduced 5'ss usage, whereas destabilization increased splicing at this position.

Laboratory of Experimental Virology, University of Amsterdam, Amsterdam, The Netherlands

\section{Conclusions}

The stability of the SD hairpin controls the level of splicing at the major 5'ss. The wild-type SD hairpin structure inhibits 5'ss usage to a level that results in an optimal balance between unspliced and spliced RNAs for efficient virus replication.

Published: 19 September 2013

doi:10.1186/1742-4690-10-S1-P62

Cite this article as: Mueller et al:: The RNA structure of the major splice donor site controls HIV-1 splicing. Retrovirology 2013 10(Suppl 1):P62.
Submit your next manuscript to BioMed Central and take full advantage of:

- Convenient online submission

- Thorough peer review

- No space constraints or color figure charges

- Immediate publication on acceptance

- Inclusion in PubMed, CAS, Scopus and Google Scholar

- Research which is freely available for redistribution
() Biomed Central 